\title{
Ascertaining The Quality of The Translated Version of The New Cameroon Penal Code
}

\author{
Wanchia T. Neba, PHD \\ Advanced School Of Translators And Interpreters (ASTI) \\ University Of Buea, Cameroon \\ Nguedjeu-Momekam A. Amos, MA \\ Advanced School Of Translators And Interpreters (ASTI) \\ University Of Buea, Cameroon
}

\begin{abstract}
This article has a three-fold objective - to identify and describe revision-related errors found in the New Cameroon Penal Code. It also attempts to determine the degree of semantic shift per error type. Finally, it proposes a solution to each characteristic category of errors identified. The exercise relies on the Translation Quality Assessment models of Gouadec (grammatical correctness), Waddington (contre-sens) and Juliane House's Functional Pragmatism. These models are supplemented by Toury's Descriptive Translation Studies model by which the excerpts are chronologically analysed against the backdrop of a 10-point tabular grid. Findings reveal that of the 372 sections which comprise the new Cameroon Penal Code, $45(0.001+\%)$ had errors. Four main translation errors were found - omission, contre-sens, inadequacy and inconsistency. Of these, inadequacies had the highest frequency with $51.11+\%$. Both omission and contre-sens had the same frequency $(17.77+\%)$ while inconsistency had the lowest frequency $(13.33+\%)$. Subsequently, five (5) excerpts selected from the 50 translation errors discovered in the new Cameroon Penal Code have then been effectively evaluated, using both qualitative and quantitative methods to determine the potential causes of deviation. In this vein, the translator's reliance on the communicative instead of the socio-linguistic translation approach proved counterproductive. Notwithstanding, identified translation shortcomings do not invalidate the document's usability, pedagogically and professionally speaking. On the whole, this exercise underscores the importance of revision in not only with regard to translation quality assurance in general but equally to the New Cameroon Penal Code as a case study.
\end{abstract}

Key concepts: Translation Quality, Assessment, Revision, New Cameroon Penal Code, Descriptive Translation Studies.

\section{INTRODUCTION}

Cameroon is a central African country of $475.000 \mathrm{~km}^{2}$, with a population of 19 million (2010 population census figures) inhabited by peoples of diverse ethnic groups with very few shared similarities - the Bantu in the Centre, South and East Regions, Semi-Bantu mainly in the West Region, and the Fulbe and Sudanese in the Adamawa, North and Far North Regions. Cameroon thus has a peculiar and complex linguistic setting. Bretton \& Fothung (1991:20, in Anchimbe, 2006:44) have reported two official languages (English and French), a pidgin English, "Camfranglais", over eight regional lingua francas (Fulfulde, Ewondo, Basa, Duala, Hausa, Wandala, Kanuri, and Arab Choa) and an unspecified number of home/national languages. However, for the purpose of this article, only English and French as official languages are in focus. 
The defeat of the Germans in World War II ushered in the French (the first entry) and the English (the second and educated English entry) through the Treaty of Versailles (1919). The end of World War I coincided with the death of German as an international lingua franca. In the new dispensation, French replaced German in East Cameroon annexed by France and English in Southern Cameroons annexed by the British. In order to completely eradicate German, English and French were completely declared official languages in each of the separately administered territories. While Southern Cameroons was administered from Nigeria where educated English had earlier on gained substantial influence through church missionary bodies and elementary and adult school programmes, East Cameroon, for its part, was administered directly from France through the intermediary of resident French governors and administrators (Wanchia, 2012).

At the 'reunification' in 1961, both French and English were declared official languages of the Federal Republic of Cameroon, having thus been endowed with the unique originality of European-language bilingualism (Tchoungui, 1983:93). The situation remained thus even with the advent of the United Republic in 1972. Moreover, when the country became the Republic of Cameroon once more in 1984, the status remained unchanged. Indeed, Section 1.1.5 of the revised Constitution of 1996 (Law No. 96/06 of 18 January 1996) states that "The official languages of the Republic of Cameroon shall be English and French, both languages having the same status. The State shall guarantee the promotion of bilingualism throughout the country".

On account of the above, Cameroon is thus considered bilingual, bicultural, and bi-jural. While common law, for instance, remained practised by the people formerly called Southern Cameroons, the civil law system was, for its part, practised by the people of the Frenchspeaking former Republic of Cameroon.

This remained so until of recent when happenings in Cameroon seem to have put this status to test. More pointedly on November 26 2016, Cameroon's bilingual, bicultural and bi-jural character were undeniably questioned - the educational and legal sectors came under 'real attack' with far-reaching effects till date, as epitomised by the common law lawyers' strike that was followed by that of the education sector. Both English-speaking subsystems decried what they called 'infiltration and dilution' of these two sectors of their subsystem by francophones. More specifically concerning the legal domain, though the posting of francophone legal functionaries to common law jurisdictions was the main bone of contention in the legal sector, the underlying issue may be summed up as that of the language and practices used in the common law courts. Common law practitioners more specifically pointed to the abusive use of French language in common law courts - either the direct use of French to the Englishspeaking or the use of poorly translated 'English versions' of texts.

This last issue is the subject of this article which sets to assess the usability of the new Cameroon Penal Code (CPC), which had just been recently translated from French (its usual language of conception) into English, in the process of attempting to harmonise the legal system. From the foregoing, this analysis relies on Suh's (2017) stance of "zero tolerance" of translation errors in legal documents.

It first and foremost identifies and describes revision-related errors contained in the New Cameroon Penal Code. Secondly, it demonstrates not only how each error type was committed in the translated English version but how it affected meaning. Finally, it proffers a remedy to each representative category of committed errors. On the whole, this article therefore attempts to ascertain the degree of acceptability of the translated version of the new CPC, in the context of the socio-political malaise hereabove painted. 
After the introduction, this article is further developed over four other major highlights, viz., examining the issue of translation quality assurance in general, reviewing quality assurance in legal translation in particular, ascertaining the quality of the new Cameroon Penal Code before a conclusion that ends the article. They are presented below in that order.

\section{TRANSLATION QUALITY ASSURANCE IN GENERAL}

Gouadec (2007: 88) avers that translators are not interpreters. He adds that amongst other things,

Translators always translate written material or coded or transcribed pre-recorded speech. This usually implies a time-lag between the moment the material is produced and the time when it is translated - notable exceptions being documents or content that are produced bilingually or multilingually straightaway and in parallel. Translation essentially has to do with written (or graphic) material.

Robinson (2007: 23) says translators are voracious readers and most especially people who "are hungry for real-world experience as well, through travel, living abroad for extended periods, learning foreign languages and cultures, and above all paying attention to how people use language all around them: the plumber, the kids' teachers, the convenience store clerk, the doctor, the bartender, friends and colleagues from this or that region or social class, and so on." It is a profession that requires assiduity, patience and humility (willingness to learn and inquire when one is faced with an impasse).

Paying attention to how people use language all around them is done all in the effort to uphold quality which in turn requires the need for a code of ethics. Benadana \& Melby (2012: 64) emphasize on the need for a Code of Ethics to guide translators and Translator Service Providers (TSP) since translation has become an industry with several practitioners making a living out it. Therefrom, several national and international organisations (Association of Canadian Corporations in Translation and Interpretation known by its acronym ACCTI (Bendana \& Melby, 2012: 48) and APTIC - the Association of Professional Translators and Interpreters in Cameroon) amongst others have seen the light of day by bringing professional translators and interpreters together to ensure quality in translation.

Translation quality - conceptualising and measuring - is quite primordial in Translation Studies. However, before getting there, it is important to trace another intricate link that exists between quality and the interdependent construct of 'translation'.

Translation, either as a product or process, does not have a standard or clear-cut definition. It has been viewed differently by scholars depending on their perspectives. Due to its variegated nature, translations can be classified by subject matter or "domain". According to Gouadec (2007: 11), we have literary translation, technical translation, medical translation, economic translation, financial translation, legal translation (the focus of this paper), translation of marketing and promotional documents, translation of ICT documents. Other types of translation are specific to various sciences, subject areas or economic sectors.

ISO 8402 (1994: 3.1), amongst many stakeholders, avers that quality is "the totality of features and characteristics of a product or service that bear on its ability to satisfy stated or implied needs". Muzii (2006) also perceives quality as "an integration of the features and characteristics that determine the extent to which output satisfies the customer's needs". Quality therefore implies the existence of "defects", defined by ISO 8402 (1994: 3.1) as the "non-fulfilment of intended usage requirements". 
Simply put, Translation Quality Assessment (TQA) “discusses the worth of translation through examining the relationship between a source text and its translation based on a comparison analytical evaluation" (Madkour, 2016: 93), citing House (2001). This conceptualisation will end with the statement that "There is more to translation quality than absence of errors; a translated text must be easy to read, even if the original is not very clear" (European Commission, 2012: 14). Quality assurance can be said to pass through three essential phases pre-translation, translation and post-translation.

\section{Translation Quality Assurance Phases}

Pursuant to Gouadec (2007: 12-13), activities involved in providing a translation service are organised in three phases, that is, pre-translation, translation and post-translation.

a) Pre-translation includes everything that takes place up to the moment the translator actually receives the material for translation: everything that has to do with getting the job, writing out estimates, negotiating, getting the specifications right, contracting...

b) Translation, in turn, is divided into three stages: pre-transfer, transfer and posttransfer. Pre-transfer, includes preparation of the material, documentary searches, alignment, memory consolidation, terminology mining, deciding on options inter alia. Transfer is the actual moment when one shifts from one language to the other (the act of translating) while post-transfer mostly pertains to quality control and upgrading (ensuring the work meets with the quality requirements and criteria prior to delivery). It includes formatting and various preparations for delivery (which is the focus of this paper).

c) Post-translation, on its part, covers all activities that follow delivery of the translated material such as "possible integration of the translated material (as in simulation of subtitles, layout prior to publishing, integration in a Web site or in an international soundtrack, etc.) but also, of course, all the "administrative" business of getting paid, setting up an archive of the project, consolidating the terminology for future uses, and much more" (Gouadec, 2007: 13).

A translator executes several quality assuring tasks when given written material to translate, one of which is revision - a post-transfer exercise that is examined below.

\section{Translation Quality Assurance by Revision}

Revision is a post-transfer exercise. During post-transfer, the translator seeks to improve upon the quality of the translation s/he has carried out in order to meet certain requirements and standards. Sunkova (2011: 10) opines that in generic terms, "revision can be understood as checking a product of a drafting activity (most often a piece of writing, e.g. a law) in order to make sure it constitutes an acceptable outcome, and possibly changing it." The aforementioned scholar does not end here. He/she (2011: 10-11) further avers that:

...In a narrower sense and already within the field of translation, revising generally signifies assuring that a translation is acceptable and of a required quality. We can perceive it as a process which includes finalising, checking, proofreading, and amending a target text. Thirdly, in its most concrete sense of the word, revision constitutes a particular stage in the wind-up process of translation during which a reviser reads the target text once again, compares the source text against the target text, looks for any possible inaccuracies, mistakes of transfer of meaning, grammatical and stylistic errors and much more.

Robert (2008:5) says revision refers either to the process of revising one's own translation, or to the process of revising somebody else's translation. The European Committee for Standardisation (2006: 6) states: "to revise: to examine translation for its suitability for the 
agreed purpose, compare the source and the target texts and recommend corrective measures."

From the aforementioned definitions, revising translations is very important as it improves upon the quality of translations. It equally curbs, not to say totally eradicates errors. For better quality, Sunkova (2011: 13) suggests that it is preferable to have one's translation revised by a third party as it would shun familiarity and give place to constructive objectivity.

Revision is a contextualised activity. It is against this backdrop that the New Cameroon Penal Code is evaluated. In other words, its acceptability is assessed within a Cameroonian context, paying keen attention to all its contextual socio-political ramifications.

\section{TRANSLATION QUALITY ASSURANCE AND LEGAL TEXTS}

Quality in legal translation is a function of legal diction and the problems emanating therefrom.

i) Legal diction: Legal language is one of the most complex specialised forms of language and so are the difficulties inherent to it. Language is a means of communicating the law. Thus, this type of communication is subject to a number of stylistic, syntactic, semantic and lexical rules. These rules are set based on the hierarchy of norms put down by the legislator. Therefore, those who employ Legal language must respect these principles. Hence, the specificity of this specialized form of language helps to give the law an efficient and imperative nature which is necessary to organize behavioural patterns in society.

Legal terminology is broad and emanates from various sources. Many terms which are used in common usage have peculiar meanings while others can only be found within the framework of law. Some terms were borrowed from other languages, especially Greek and Latin. Furthermore, the meaning of these terms is often circumscribed by context, and that is why legal language, which is sui generis, is one of the most polysemic languages (Zangue, 2014)

In terms of style, the language of the law can characterise a speech. In French, for example, the language of law distinguishes itself from other languages by lining up different parts of speech in a particular way. For example, in legal discourse, the verb is usually placed at the beginning of a sentence and it is characterized by winding sentences. Legal language is equally redundant. For clarity sake, the legislator repeats words. Moreover, the tone used in language of the law is formal, thereby shunning any iota of familiarity. It is this tone that reinforces the imperative nature of the law.

ii) The (un)translatability of legal diction: Some Translation Studies scholars aver that legal concepts are untranslatable. However, the issue of translatability stems from a cultural view point because legal concepts are intertwined with culture since language varies from one culture to another. The question of translatability has been discussed from different angles, to wit, from a universal, relative and deconstruction point of view.

A text may have different interpretations. Thus, can one ascertain that these interpretations could always thwart or "deconstruct" the meaning of a particular text? If that is the case for isolated signifiers, could it be same for a given text? Given the particular context in which a signifier is used, would it mean that the meaning is always thwarted? Considering that a text can be interpreted in many ways, these interpretations have limits. The context of the signifiers will always guide the reader 
(translator) to interpret it adequately, hence creating a link between translation and context.

\section{Constraints to Translating Legal Diction}

Legal translation must take into account elements within the fabric of the law. Law is made up of elements which have a ripple effect on one another; that is, law is a social phenomenon used by language which in itself is a social tool. The law imposes a norm using language which has obeyed certain principles to which the law has equally been subjected to. Moreover, the translation of texts necessitates the adaptation of a product from one culture to another, since law is a social phenomenon. These features make legal translation an activity with a plethora of difficulties. The jurilinguist, Gemar (1979: 35-63) outlined types of problems inherent to legal translation, which stem from:

i) The normative character or constraint of legal texts which gives the translator very little room to choose from available linguistic resources (the translator must be able to distinguish between a faithful and free/liberal legal translation method).

ii) The discourse (language) of the law, its vocabulary, techniques, mechanisms, institutions, notions and any other phenomena within the area of law. The terminological basis of law is very broad.

iii) The social and political diversity of legal systems, that is, the distinguishing features within each legal system.

iv) The elements that influence documentary search: The field of law is characterised by a wide array of polysemic terms (with different meanings) which make it difficult to adapt them given the social, economic and cultural conditions of a given society.

v) The necessity to follow a multidisciplinary approach to law: The legal translator must have been trained in the areas of law and languages. Legal translation equally demands that the translator has some knowledge in economics, sociology, history and even philosophy. For example, Commercial law requires knowledge in taxation.

The aforementioned problems enumerated by Gemar can be encountered in the course of translating legal texts. In addition to these, pragmatic issues like respect for deadlines and conditions under which the translator works, particularly, the role he plays within a particular context have to be taken into consideration. In order to circumvent these difficulties, a legal translator uses the techniques prescribed by experts in this field.

\section{Perspectives on The Translation of Legal Diction}

Cao (2010: 191) defines legal translation as a translational activity that involves the language of and is related to law. Fonkenmun (2007: 72-73) cautions that legal translation is a special kind of translation which requires precision. She posits that:

Legal translation demands precision because unlike other types of translation, it is specialised, technical and has specific equivalents contrary to general translation where one can have several acceptable translations for the same phrase and several acceptable equivalents for any given term or word...A translator has to master the culture as well as the history of the countries or States involved given that the language of the law is so closely interwoven with its culture and any attempt to separate them will breed artificiality and result in presumptuous and erroneous translations.

Stolze (2013: 61) strongly asserts that "Legal translation is impossible without a prior understanding of the given text." 


\section{ASCERTAINING THE QUALITY OF THE NEW CAMEROON PENAL CODE}

Fonkenmun (2007: 56), states that the Cameroon Penal Code was enacted by Law No 65-LF-24 of 12 November 1965 and came into force on 12 April 1966. She (2007: 57) further adds that the Penal Code was supplemented by Law No 90/061 of 19 December 1990. Worthy of note is the fact that the Penal Code was not entirely revised. In that vein, and pursuant to Eyike-Vieux (2017), only some sections of the Penal code were revised. Some were re-written while other provisions were added to punish more offences. Cameroon Tribune (2016) reports that according to Kenfack Douajni Gaston, PhD (Director of Legislation at the Ministry of Justice), the Keeper of the Seals narrowed down the debate to nearly 100 new or modified sections out of the 372 Sections of the Penal Code.

Its new constitution stands as follows: Section 1 of the new Penal Code states that the Penal Code is composed of two parts: Book I comprising Sections 1 to 101 and Book II comprising Sections 102 to 361 . There are equally the regulatory provisions of the Penal Code which define simple offences, comprising Sections 362 to 370, while Sections 371 and 372 lay down the transitional and final provisions.

\section{Identifying and describing error types in the new Cameroon Penal Code}

While reading through this document, some error types highlighted below were discovered (like in every human endeavour). They have been highlighted below.

a) Omission in Translation: Icoz (2012: 132) defines omission as "the elimination or reduction of a part of a text." Tso (2010) on his part, opines that omission in translation could be both favourable and unfavourable depending on the situation:

Omission in translation is normally considered unfavourable because during the process of omission, some information or effect in the ST will be omitted and therefore lost. While omission is carried out when the content is intentionally or unconsciously deleted by the translator (because of censorship, standardization, or/and the translator's wish to eliminate redundant and irrelevant elements to 'improve' the ST), sometimes, omission also occurs when certain qualities in the SL cannot be kept in the TL (Tso, 2010: 27).

b) Inconsistencies: The European Union (2015: 5-6), states that "Translation errors and discrepancies may also result in difficulties and problems - and potentially errors - of interpretation and implementation at the national level." Inconsistency has to do with dissimilarities between the source text and the target which hampers uniform implementation of a legal document.

c) Contre-sens: Dussart (2005: 107) opines that the effect of contre-sens in translation is that it contradicts the thoughts of the author of a text, document making the translation to appear to be unrealistic when compared with the source text. It is a negative shift in meaning.

d) Inadequacy: According to Nord (1991: 35), "adequacy" refers to the qualities of a target text with regard to the translation brief: the translation should be 'adequate' to the requirements of the brief.' Moreover, adequacy can equally be seen at the level of using words within their right context.

\section{Error types found in the new Cameroon Penal Code}

A keen scrutiny of and analysis of the new Cameroon Penal Code (CPC) shows that of 372 sections which comprise the new Cameroon Penal Code, forty-five (45) had errors. Out of these 45 sections, eight (8) had an issue of omission (17.77\%). Contre-sens also featured eight (8) times (17.77\%). Six (6) portions had a problem of inconsistencies (13.33\%), while twenty-three 
(23) areas had issues of inadequacy (51.11\%). From these statistics, it is clear that inadequacy had the highest frequency (51.11+\%); both omission and contre-sens had the same frequency $(17.77+\%)$ while inconsistency had the lowest frequency $(13.33+\%)$.

\section{Determining the degree of semantic shift per error type}

The part that follows attempts to determine the degree of semantic shift per error type found in the new Cameroon Penal Code. The methodology in view of determining the degree of semantic shift comprises both theoretical and procedural inputs.

\section{Theoretical Considerations}

Though there exist several theories/models/approaches to understanding and explaining translation phenomena, this section will present and examine only those applied to this exercise, viz three general translation models, two specific translation theories, two translation strategies, and the Descriptive Translation Studies (DTS) model, in that order.

\section{a) Applicable general translation models}

This paper earmarks three main theoretical Translation Quality Assessment (TQA) models that will be used to analyse and propose improvements upon the sections of the new Cameroon Penal Code that have been selected. They are: Gouadec's TQA model on grammatical correctness, Waddington's TQA model on "contresens" and House's Functional Pragmatic model on TQA, as well as Toury's Descriptive Translation Studies (DTS) model - all used to describe the translations effected by the translator(s) of the new Cameroon Penal Code and the researchers.

i) Larose (1998: 14-15) states that any translation should solely be assessed on the negative impact it is likely to have on the Target audience. However, not every language lacuna may have a negative impact. Notwithstanding, grammatical lapses should be addressed to make a translation "consumable."

ii) Karimnia \& Shahrahi (2011: 5220) have averred that some of the inappropriate renderings lead to contre-sens. Contre-sens is a serious translation error that thwarts the meaning of a Source Text.

iii) Thirdly, House's Functional Pragmatic model, evolved from her maiden 1977 model has a contribution to offer. House (2015:142) authoritatively states that "any evaluation depends on a large variety of factors that necessarily enter into a social evaluative judgement. This judgement emanates from the analytic, comparative process of translation criticism, i.e. it is the linguistic analysis which provides grounds for arguing social evaluative judgement." House's model is particular about the context of production of a given translation since translations are not produced in a vacuum, and most often, they are produced at the whims and caprices of the donor (client). The new Cameroon Penal Code is not left out. However, Eyike-Vieux (2017) is unaware about the translators of this criminal law.

iv) Finally, there is Toury's Descriptive Translation Studies model which is captured by Nguedjeu-Momekam (2017: 53) as:

a strategy that focuses on the process of translating, the function of the translation and the end product that should reflect its function. In other words, it is the theoretical and descriptive approaches to translating through which translation phenomena are described, explained and predicted.

\section{b) Applicable translation theories}

All translators, either knowingly or otherwise, resort to an idealized translation process that can be described in theoretical terms. This theoretical framework underpins their translation choice in that it determines a translation strategy. In the following we have tried to identify the theoretical framework and the strategy employed by the translators of the Penal code based on 
the end result achieved. We then proceed to evaluating whether these choices were appropriate in the context and subsequently suggest a different option, based on an alternative theoretical framework and strategy. In light of the above, two theories and two strategies are of essence to to this discussion. The theories considered here are the Socio-linguistic and Communicative theories. They are briefly described, in that order, in the sections that follow, beginning with the theories.

i) Socio-linguistic Theory: The thrust of this theory is that cultural realities of the receptors should be taken into consideration while using language, and resources of the target audience should be exploited so as to enable the target readership to understand the message. A proponent of this theory is Newmark (1988). Legal translation leads to a direct intercourse between two legal systems, thus, it is important to know the nitty-gritties of both legal systems that are involved to produce acceptable translations.

ii) Communicative Theory: Nguedjeu-Momekam (2017:44) states: "The Communicative theory posits that the translator attempts to produce the same effect on the target language readers as was produced to the source language readers." Communicative translation attempts to produce on its readers an effect as close as possible to that obtained on the readers of the original (Newmark, 1981: 39). As seen above, the aim of translation is to communicate effectively in another language what has been said in a given language. Legal translation should be void of any ambiguities that might lead to unequal application of a law.

\section{c) Applicable translation strategies}

In order to translate the new Cameroon Penal Code, the translator employed a number of strategies. However, this paper pointedly limits itself only to the strategies used in the excerpts analysed. These strategies - formal and functional equivalence - are briefly described below, in that order.

i) Formal equivalence: According to Nida (1964: 165) "formal equivalence translation is basically source text-oriented, that is, it is designed to reveal as much as possible of the form and content of the original message." This strategy is also called literal translation, because it tries to preserve the semantic content of the SL (Source Language) term intact for the TL (Target Language) users.

ii) Functional equivalence: Darani (2013:5) postulates that legal functional equivalence is "a term in the target legal system, designating a concept or institution, the function of which is the same as that in the source legal system." This strategy is important as some legal terms do not have glaring equivalences. It is left for the legal translator to find a term that has the same function in the target language. This enables him/her to produce what Kockaert \& Rahab (2017: 6) term "fit-for-purpose translations."

\section{Procedural Inputs}

Procedurally, the proposed framework relies on a grid inspired by Wanchia (2016: 25). Sample excerpts for analysis are extracted from each category of the new Cameroon Penal Code (Law No 2016/007 of 12 July 2016 and Decree No 2016/319 of 12 July 2016) published in the Special Edition (15 July 2016) of Cameroon Tribune, according to a ten-step chronologized procedure as follows:

a) Source Text: Presents the French version of the excerpt under study.

b) Target Text: Presents the excerpt under study.

c) Context of Production: Specifies the context of the source text excerpt.

d) Textual Element(s) of Interest: Identifies the general target text textual element(s).

e) Specified Element(s) of Interest: Identifies the specific element(s) from wider text.

f) Translator's Method: 
i) Translation theory used: Highlights the translator's theory(ies) used to produce the target text.

ii) Translation strategy used: Highlights the translator's strategy(ies) used to produce target text.

g) Value Judgement: Assesses the Target text.

h) Proposed Translation: Suggests a translation for the element of interest.

i) Researcher's Method:

i) Translation theory used: Presents which translation theory(ies) are useful for the exercise.

ii) Translation strategy used: Presents translation strategy(ies) used for the exercise.

j) Justification of Researcher's Method: Presents an argument for the translation proposed by the researcher.

\section{Justifying the presence and impact of each error category}

Four (4) excerpts, each from the category of omission, inconsistency, contre-sens and inadequacy identified in the document have then been analysed as per the grid above.

\section{Excerpt 1: Category of omission}

Table 1: Identifying, describing and evaluating omission-related error

\begin{tabular}{|c|c|c|c|}
\hline a & Source Text & \multicolumn{2}{|c|}{$\begin{array}{l}\text { Article } 1 \text { (c)- Le décret portant partie réglementaire du Code Pénal définissant } \\
\text { les contraventions, des articles } 362 \text { à } 370 ;\end{array}$} \\
\hline $\mathrm{b}$ & Target text & \multicolumn{2}{|c|}{$\begin{array}{l}\text { Section } 1 \text { (c)- The decree relating to regulatory provisions of the Penal Code } \\
\text { which define offences, comprising Sections } 362 \text { to } 370 \text {; }\end{array}$} \\
\hline $\mathrm{C}$ & Context of production & \multicolumn{2}{|c|}{ It is an article that gives an overall content of the new Cameroon Penal Code. } \\
\hline $\mathrm{d}$ & $\begin{array}{l}\text { Textual Element(s) of } \\
\text { Interest }\end{array}$ & \multicolumn{2}{|l|}{ Offences } \\
\hline e & $\begin{array}{l}\text { Specified Element(s) } \\
\text { of Interest: omission }\end{array}$ & \multicolumn{2}{|l|}{ Simple (Offences) } \\
\hline \multirow[t]{2}{*}{$\mathrm{f}$} & Translator's Method & $\begin{array}{l}\text { a) Translation } \\
\text { Theory }\end{array}$ & $\begin{array}{l}\text { Communicative Theory. The translator rendered } \\
\text { contraventions by offences, thereby giving a } \\
\text { blanket term to its French equivalent. }\end{array}$ \\
\hline & & $\begin{array}{l}\text { b) Translation } \\
\text { Strategy }\end{array}$ & $\begin{array}{l}\text { Functional equivalence. The translator decided } \\
\text { to deculturise the cultural word to give a term that } \\
\text { has the same function as that in the Source } \\
\text { Language. }\end{array}$ \\
\hline g & Value judgement & \multicolumn{2}{|c|}{$\begin{array}{l}\text { The translator did not take into account the fact that 'contraventions' are not } \\
\text { only offences, but they are offences of a special kind (simple); it is a contre- } \\
\text { sens. Legal terms must be used in their right context. As a result, the translation of } \\
\text { this section of the PC is unsuccessful. }\end{array}$} \\
\hline $\mathrm{h}$ & Proposed Translation & \multicolumn{2}{|c|}{$\begin{array}{l}\text { Section } 1 \text { (c)- The decree relating to regulatory provisions of the Penal Code } \\
\text { which define simple offences, comprising Sections } 362 \text { to } 370 \text {; }\end{array}$} \\
\hline \multirow[t]{2}{*}{$\mathrm{i}$} & Researcher's method & $\begin{array}{l}\text { a) Translation } \\
\text { Theory }\end{array}$ & $\begin{array}{l}\text { Socio-linguistic theory. The thrust of this theory } \\
\text { is reproducing the equivalent term of a source text } \\
\text { in the target text and that is recognised in the } \\
\text { target language culture. }\end{array}$ \\
\hline & & $\begin{array}{l}\text { b) Translation } \\
\text { strategy }\end{array}$ & $\begin{array}{l}\text { Formal equivalence: The translator uses a pre- } \\
\text { existing cultural element in the target culture } \\
\text { recognised as an equivalent of the source text. }\end{array}$ \\
\hline $\mathrm{j}$ & $\begin{array}{l}\text { Justify Researcher's } \\
\text { method }\end{array}$ & \multicolumn{2}{|c|}{$\begin{array}{l}\text { For specificity sake, since the word 'simple' was omitted, it was necessary to use } \\
\text { the socio-linguistic theory and formal equivalence strategy to find a Target } \\
\text { language term that best suits as the English equivalent of 'contraventions' and is } \\
\text { naturally close to the Source language. The word 'contraventions' is not only an } \\
\text { offence but it is a special kind of offence provided for by Section } 21 \text { of the PC. }\end{array}$} \\
\hline
\end{tabular}




\section{Excerpt 2: Category of inconsistency}

Table 2: Identifying, describing and evaluating inconsistency-related error

\begin{tabular}{|c|c|c|c|}
\hline $\mathrm{a}$ & Source Text & \multicolumn{2}{|c|}{$\begin{array}{l}\text { Article } 80 \text { (2) - Le mineur de dix (10) à quatorze (14) ans, pénalement responsable, } \\
\text { ne peut faire l'objet que de l'une des mesures spéciales prévues par la loi. }\end{array}$} \\
\hline $\mathrm{b}$ & Target text & \multicolumn{2}{|c|}{$\begin{array}{l}\text { Section } 80 \text { ( } 2 \text { )-An offence committed by a person aged not less than } 10 \text { (ten) years } \\
\text { and not less than } 14 \text { (fourteen) years may attract only such special measures as } \\
\text { may by law be provided. }\end{array}$} \\
\hline $\mathrm{c}$ & $\begin{array}{l}\text { Context of } \\
\text { production }\end{array}$ & \multicolumn{2}{|c|}{$\begin{array}{l}\text { It is an article that gives special measures to be imposed to any minor aged between } \\
10 \text { and } 14 \text { who commits an offence. }\end{array}$} \\
\hline $\mathrm{d}$ & $\begin{array}{l}\text { Textual } \\
\text { Element(s) of } \\
\text { Interest }\end{array}$ & \multicolumn{2}{|c|}{ not less than 14 and as may by law be provided. } \\
\hline $\mathrm{e}$ & $\begin{array}{l}\text { Specified } \\
\text { Element(s) of } \\
\text { Interest: } \\
\text { inconsistency }\end{array}$ & \multicolumn{2}{|c|}{ Less than \& as may by law be provided } \\
\hline \multirow[t]{2}{*}{ f } & \multirow[t]{2}{*}{$\begin{array}{l}\text { Translator's } \\
\text { Method }\end{array}$} & a) Translation Theory & $\begin{array}{l}\text { Communicative Theory. The thrust of this } \\
\text { theory is that the translation should produce the } \\
\text { same effect on the target language readers as on } \\
\text { the source language readers. }\end{array}$ \\
\hline & & b) Translation Strategy & $\begin{array}{l}\text { Functional equivalence. The translator sought to } \\
\text { give a translation that has the same function as } \\
\text { that in the Source Text. }\end{array}$ \\
\hline g & Value judgement & \multicolumn{2}{|c|}{$\begin{array}{l}\text { The translator did not handle the first part of this section well as he wrote the } \\
\text { opposite (contre-sens) of what the Source text means. With regard to the second } \\
\text { part, he failed to render the idiomatic legal expression when talking about provisions } \\
\text { of the law. As a result, the translation of this section of the PC is unsuccessful. }\end{array}$} \\
\hline $\mathrm{h}$ & $\begin{array}{l}\text { Proposed } \\
\text { Translation }\end{array}$ & \multicolumn{2}{|c|}{$\begin{array}{l}\text { Section } 80 \text { (2) - An offence committed by a person aged not less than } 10 \text { (ten) years } \\
\text { and not more than } 14 \text { (fourteen) years may attract only such special measures as } \\
\text { may be provided by law. }\end{array}$} \\
\hline \multirow[t]{2}{*}{$\mathrm{i}$} & $\begin{array}{l}\text { Researcher's } \\
\text { method }\end{array}$ & a) Translation Theory & $\begin{array}{l}\text { Socio-linguistic theory. The thrust of this } \\
\text { theory is reproducing the equivalent term of a } \\
\text { source text in the target text and that is } \\
\text { recognised in the target language culture. }\end{array}$ \\
\hline & & b) Translation strategy & $\begin{array}{l}\text { Functional equivalence: The thrust of this } \\
\text { strategy is to find a translation that has the } \\
\text { same function as the provisions in the Source } \\
\text { text. }\end{array}$ \\
\hline j & $\begin{array}{l}\text { Justify } \\
\text { Researcher's } \\
\text { method }\end{array}$ & \multicolumn{2}{|c|}{$\begin{array}{l}\text { The Socio-linguistic theory and functional equivalence strategy make the } \\
\text { proposed translation closely natural to the article in the French version of the Penal } \\
\text { Code. The expression proposed "as may be provided by law" is more idiomatic and } \\
\text { grammatically correct than the one proposed by the translator. }\end{array}$} \\
\hline
\end{tabular}




\section{Excerpt 3: Category of contre-sens}

Table 3: Identifying, describing and evaluating contre-sens-related error

\begin{tabular}{|c|c|c|c|}
\hline $\mathrm{a}$ & Source Text & \multicolumn{2}{|c|}{$\begin{array}{l}\text { Article 163- Est puni d'un emprisonnement d'un (01) mois à trois (03) ans et } \\
\text { d'une amende de vingt-cinq mille }(25000) \text { à deux millions ( } 2000000) \text { de francs } \\
\text { ou de l'une de ces deux peines seulement, celui qui commet une fraude dans les } \\
\text { examens ou concours dans le but d'obtenir soit l'entrée dans un service public, soit } \\
\text { un diplôme, certificat ou titre délivré par l'Etat ou un service public national ou } \\
\text { étranger. }\end{array}$} \\
\hline $\mathrm{b}$ & Target text & \multicolumn{2}{|c|}{$\begin{array}{l}\text { Section 163- Whoever commits any fraud at an examination or competition with } \\
\text { intent thereby to procure his entry into any public service, or any degree certificate } \\
\text { or qualification issued by the State or by a public service, whether national or } \\
\text { foreign shall be punished with imprisonment for from } 1 \text { (one) month to } 3 \text { (three) } \\
\text { years or with fine of from CFAF } 25000 \text { (twenty-five thousand) to CFAF } 2000000 \\
\text { (two million), or with both such imprisonment and fine. }\end{array}$} \\
\hline $\mathrm{C}$ & $\begin{array}{l}\text { Context of } \\
\text { production }\end{array}$ & \multicolumn{2}{|c|}{ It is an article that punishes fraud at examinations. } \\
\hline $\mathrm{d}$ & $\begin{array}{l}\text { Textual } \\
\text { Element(s) of } \\
\text { Interest }\end{array}$ & \multicolumn{2}{|l|}{ competition } \\
\hline $\mathrm{e}$ & $\begin{array}{l}\text { Specified } \\
\text { Element(s) of } \\
\text { Interest: contre- } \\
\text { sens }\end{array}$ & \multicolumn{2}{|l|}{ competition } \\
\hline \multirow[t]{2}{*}{$\mathrm{f}$} & \multirow[t]{2}{*}{$\begin{array}{l}\text { Translator's } \\
\text { Method }\end{array}$} & $\begin{array}{l}\text { a) Translation } \\
\text { Theory }\end{array}$ & $\begin{array}{l}\text { Communicative Theory. The thrust of this theory is } \\
\text { that the translation should produce the same effect on } \\
\text { the target language readers as on the source language } \\
\text { readers. }\end{array}$ \\
\hline & & $\begin{array}{l}\text { b) Translation } \\
\text { Strategy }\end{array}$ & $\begin{array}{l}\text { Functional equivalence. The translator sought to give a } \\
\text { translation that has the same function as that in the } \\
\text { Source Text. }\end{array}$ \\
\hline $\mathrm{g}$ & $\begin{array}{l}\text { Value } \\
\text { judgement }\end{array}$ & \multicolumn{2}{|c|}{$\begin{array}{l}\text { The translator did not handle the second type of examination and rendered a } \\
\text { contre-sens. As a result, the translation of this section of the PC is unsuccessful. }\end{array}$} \\
\hline $\mathrm{h}$ & $\begin{array}{l}\text { Proposed } \\
\text { Translation }\end{array}$ & \multicolumn{2}{|c|}{$\begin{array}{l}\text { Section 163- Whoever commits any fraud at an examination or competitive } \\
\text { examination with intent thereby to procure his entry into any public service, or } \\
\text { any degree certificate or qualification issued by the State or by a public service, } \\
\text { whether national or foreign shall be punished with imprisonment for from } 1 \text { (one) } \\
\text { month to } 3 \text { (three) years or with fine of from CFAF } 25000 \text { (twenty-five thousand) } \\
\text { to CFAF } 2000000 \text { (two million), or with both such imprisonment and fine. }\end{array}$} \\
\hline \multirow[t]{2}{*}{$\mathrm{i}$} & \multirow[t]{2}{*}{$\begin{array}{l}\text { Researcher's } \\
\text { method }\end{array}$} & $\begin{array}{l}\text { a) Translation } \\
\text { Theory }\end{array}$ & $\begin{array}{l}\text { Socio-linguistic theory. The thrust of this theory is } \\
\text { reproducing the equivalent term of a source text in the target } \\
\text { text and that is recognised in the target language culture. }\end{array}$ \\
\hline & & $\begin{array}{l}\text { b) Translation } \\
\text { strategy }\end{array}$ & $\begin{array}{l}\text { Functional equivalence: The thrust of this strategy is to find } \\
\text { a translation that has the same function as the provisions in } \\
\text { the Source text. }\end{array}$ \\
\hline j & $\begin{array}{l}\text { Justify } \\
\text { Researcher's } \\
\text { method }\end{array}$ & \multicolumn{2}{|c|}{$\begin{array}{l}\text { The Socio-linguistic theory and functional equivalence strategy make the } \\
\text { proposed translation closely natural to the article in the French version of the } \\
\text { Penal Code. When one is writing an examination which usually has limited number } \\
\text { of candidates admitted, one cannot talk of competition. Competitions are more } \\
\text { appropriate in the domain of sports. Thus, in terms of examinations, the } \\
\text { appropriate term to use is competitive examination. }\end{array}$} \\
\hline
\end{tabular}




\section{Excerpt 4: Category of inadequacy}

Table 4: Identifying, describing and evaluating inadequacy-related error

\begin{tabular}{|c|c|c|c|}
\hline $\mathrm{a}$ & Source Text & \multicolumn{2}{|c|}{$\begin{array}{l}\text { Article } 343 \text { (1) - Est puni d'un emprisonnement de six (06) mois à cinq (05) ans et } \\
\text { d'une amende de vingt mille (20 000) à cinq cent mille }(500000) \text { francs, toute } \\
\text { personne de l'un ou de l'autre sexe qui se livre habituellement, moyennant } \\
\text { rémunération, à des actes sexuels avec autrui. }\end{array}$} \\
\hline $\mathrm{b}$ & Target text & \multicolumn{2}{|c|}{$\begin{array}{l}\text { Section } 343 \text { (1)- Whoever, of either sex, who engages habitually for gain, in sexual } \\
\text { intercourse with another shall be punished with imprisonment for from } 6 \text { (six) } \\
\text { months to } 5 \text { (five) years and with fine of from CFAF } 20000 \text { (twenty thousand) to } \\
\text { CFAF } 500000 \text { (five hundred thousand). }\end{array}$} \\
\hline $\mathrm{c}$ & $\begin{array}{l}\text { Context of } \\
\text { production }\end{array}$ & \multicolumn{2}{|c|}{ It is an article that punishes the act of engaging in sexual intercourse for money. } \\
\hline $\mathrm{d}$ & $\begin{array}{l}\text { Textual } \\
\text { Element(s) of } \\
\text { Interest }\end{array}$ & \multicolumn{2}{|l|}{ Whoever... who } \\
\hline $\mathrm{e}$ & $\begin{array}{l}\text { Specified } \\
\text { Element(s) of } \\
\text { Interest: } \\
\text { inadequacy }\end{array}$ & \multicolumn{2}{|l|}{ Whoever... who } \\
\hline \multirow[t]{2}{*}{$\mathrm{f}$} & \multirow[t]{2}{*}{$\begin{array}{l}\text { Translator's } \\
\text { Method }\end{array}$} & $\begin{array}{l}\text { a) Translation } \\
\text { Theory }\end{array}$ & $\begin{array}{l}\text { Socio-linguistic theory. The thrust of this theory is } \\
\text { reproducing the equivalent term of a source text in the } \\
\text { target text and that is recognised in the target language } \\
\text { culture. }\end{array}$ \\
\hline & & $\begin{array}{l}\text { b) Translation } \\
\text { Strategy }\end{array}$ & $\begin{array}{l}\text { Formal equivalence: The translator uses a pre-existing } \\
\text { cultural element in the target culture recognised as an } \\
\text { equivalent of the source text. }\end{array}$ \\
\hline g & Value judgement & \multicolumn{2}{|c|}{$\begin{array}{l}\text { The translator forgot he used the word 'who' at the beginning of his rendering. He } \\
\text { introduced a redundancy. As a result, the translation of this section of the PC is } \\
\text { unsuccessful. }\end{array}$} \\
\hline $\mathrm{h}$ & $\begin{array}{l}\text { Proposed } \\
\text { Translation }\end{array}$ & \multicolumn{2}{|c|}{$\begin{array}{l}\text { Section } 343 \text { (1)- Whoever, of either sex, engages habitually for gain, in sexual } \\
\text { intercourse with another shall be punished with imprisonment for from } 6 \text { (six) } \\
\text { months to } 5 \text { (five) years and with fine of from CFAF } 20000 \text { (twenty thousand) to } \\
\text { CFAF } 500000 \text { (five hundred thousand). }\end{array}$} \\
\hline \multirow[t]{2}{*}{$\mathrm{i}$} & $\begin{array}{l}\text { Researcher's } \\
\text { method }\end{array}$ & $\begin{array}{l}\text { a) Translation } \\
\text { Theory }\end{array}$ & $\begin{array}{l}\text { Communicative Theory. The thrust of this theory is that } \\
\text { the translation should produce the same effect on the target } \\
\text { language readers as was produced to the source language } \\
\text { readers. }\end{array}$ \\
\hline & & $\begin{array}{l}\text { b) Translation } \\
\text { strategy }\end{array}$ & $\begin{array}{l}\text { Functional equivalence. The translator sought to give a } \\
\text { translation that has the same function as that in the Source } \\
\text { Text. }\end{array}$ \\
\hline $\mathrm{j}$ & $\begin{array}{l}\text { Justification of } \\
\text { Researcher's } \\
\text { method }\end{array}$ & \multicolumn{2}{|c|}{$\begin{array}{l}\text { The Communicative theory and functional equivalence strategy make the } \\
\text { proposed translation closely natural to the article in the French version of the Penal } \\
\text { Code. The redundancy has been got rid of and the translation reads naturally. }\end{array}$} \\
\hline
\end{tabular}

\section{CONCLUSION}

As stated at the outset of this article, this article set out to identify and describe revisionrelated errors found in the new Cameroon Penal Code. It also attempted to determine the degree of semantic shift per error type. Finally, it proffered a remedy to each representative category of identified errors. All this was in a bid to ascertain the degree of acceptability and usability of the document in the context of the socio-political malaise Cameroon is currently witnessing.

To achieve this, Gouadec's TQA model on grammatical correctness, Waddington's TQA model on "contresens", House's Functional Pragmatic model on TQA, as well as Toury's Descriptive Translation Studies (DTS) model were used as foundational theoretical support. In addition, the socio-linguistic and the communicative theories, alongside two main translation strategies - formal and functional equivalence were also used. From this theoretical matrix, and using the 
specified 10-point grid, four (4) excerpts, each from the category of omissions, inconsistencies, contre-sens and inadequacies, out of forty-five (45) initially identified, described and analysed were used as a demonstration of the location, origin and impact of each error type.

The three objectives of the study were attained, as revision-related errors found in the new Cameroon Penal Code were identified and described. The grid analysis in the four Tables also enabled the determination of the degree of semantic shift per error type. Finally, solution(s) to cases of inappropriate rendition were also proffered. It was discovered for instance that errors, amongst many other reasons, emanated from the translator's dependence uniquely on the communicative instead of the socio-linguistic translation approach. This proved counterproductive.

Notwithstanding these shortcomings, statistics reveal that the number of sections that were well translated far outmatch those that had translation errors. It is hence concluded that in spite of the translation errors, the new Cameroon Penal Code is worth consuming by various stakeholders, pedagogically and professionally speaking. This stance helps to avert the unequal application of the New Cameroon Penal Code within its Cameroonian setting, with all accompanying socio-cultural and political ramifications duly considered.

In all, this exercise underscores the importance, not only of revision in translation quality assurance in general, but also of the need to make sure that other factors that ensure quality assurance - text type, working conditions, environmental and other socio-political conditions, amongst others are taken into consideration.

\section{References}

Anchimbe, E. A. (2006). Cameroon English. Germany: Peter Lang GmbH.

Bendana, L. \& Melby, A. (2012). Almost everything you ever wanted to know about Translation. Canada, Toronto: Multi-Languages Corporation.

Cameroun Tribune. (2016). Interview: The New Penal Code is a stride towards Gender Equality. (online version), [Date of access: 12 August 2016].

Cao, D. (2010). Handbook of Translation Studies (Vol. 1): Legal Translation. In: Yves Gambier \& Luc van Doorslaer (2010) (eds.) Handbook of Translation Studies, Philadelphia, John Benjamins Publishing Co, pp. 191-95.

Darani, P. A. (2013). Functional Equivalence Revisited: Legal Translation in Persian and English through Parallel Corpus. In English for Specific Purposes World, 14 (39).

Decree No 2016/319 of 12 July 2016 relating to the regulatory part of the Penal Code to define simple offences (15 July 2016 Edition of Cameroun Tribune).

Dussart, A. (2005). "Faux sens, contresens, non-sens... faux débat ?" Meta 501, pp. 107-119. DOI: 10.72021010661ar.

European Commission. (2012). Studies on translation and multilingualism. Luxemburg: Publications Office of the European Union.

European Committee for Standardisation. (2006). Nederlandse norm NEN-EN 15038(en): translation services: service requirements. Brussels: Nederlands Normalisatie-institut.

Eyike-Vieux. (2017). Personal Communication, MINJUSTICE (Ministry of Justice), Yaounde, Cameroon.

Fonkenmun, E. L. (2007). The Importance of the Mastery of the Subject Field in the Translation of Legal Documents: A Case Study of the Cameroon Penal Code. Unpublished M.A Thesis in Translation, ASTI, University of Buea.

Gouadec, D. (2007). Translation as a Profession (Translated by D. Toudic \& D. Gouadec). Amsterdam \& Philadelphia: John Benjamins.

House, J. (2001). Translation quality assessment: Linguistic description versus social evaluation. Meta, 3 (2), $243-$ 257 
House, J. (2015). Translation Quality Assessment: past and present. New York: Routledge.

Icoz, N. (2012). “Considering Ethics in Translation,” in Electronic Journal of Vocational Colleges, pp. 131-134.

ISO. (1994). ISO 8402:1994 Quality management and quality assurance - Vocabulary International Organization for Standardization.

Karimnia, A. and Shahraki, A. (2011). Waddington's model of translation quality assessment: a critical inquiry. Elixir Ling. \& Trans 40, pp. 5219-5224.

Kockaert, H. J. \& Rahab, N. (2017). "Introduction: Quality in Legal Translation” in the Journal of Specialised Translation, Issue 27- January 2017, pp. 2-8.

Larose, R. (1998). Méthodologie de l'évaluation des traductions. Meta 43 (4), pp. 163-186.

Law No. 96/06 of 18 January 1996 on the Constitution of the Republic of Cameroon.

Law No. 2016/007 of 12 July 2016 relating to the Cameroon Penal Code (15 July 2016 Edition of Cameroun Tribune).

Lederer, M. (2010). Interpretative Approach. In: Yves Gambier \& Luc van Doorslaer (2010) (eds.) Handbook of Translation Studies Co, pp. 173-179, Philadelphia: John Benjamins Publishing.

Madkour, M. (2016). The Application of Functional Linguistic Models for Assessing Quality of Translation: A Descriptive Analytical Study. International Journal of English Linguistics, 6, (6), pp. 87-117.

Muzii, L. (2006). Quality assessment and economic sustainability of translation. Gruppo L10N Roma.

Newmark, P. (1988). A Textbook of Translation, [online version]: Longman.

Newmark, P. (1981). Text Book of Translation, Toronto, Shanghai: Foreign Language Education Press.

Nguedjeu-Momekam, A. A. (2017). An assessment of the Translation Quality of the new Cameroon Penal Code from French into English. Unpublished M.A Thesis in Translation, ASTI, University of Buea.

Nida, E. A. (1964). Toward a Science of Translating, Leiden: E.J Brill.

Nord, C. (1991). Text Analysis in Translation: Theory, Methodology, and Didactic Application of a Model for

Translation-oreinted Text Analysis. Translated by Christiane Nord and Penelope Sparrow, Amsterdam: Rodopi.

Robert, I. (2008). “Translation Revision Procedures: An Explorative Study” In: Pieter Boulogne (2005) (ed.) Translation and Its Others. Selected Papers of the CETRA Research Seminar in Translation Studies 2007. http://www.kuleuven.be/cetra/papers/papers.html. pp. 1-25.

Robinson, D. (2007). Becoming a Translator (2nd Ed.). New York, NY: Routledge.

Stolze, R. (2013). “The Legal Translator's approach to Texts” in Humanities 2013, 2. pp. 56-71.

Suh, J. C. (2017). Personal Communication, ASTI, Buea, Cameroon.

Sunkova, J. (2011). Revising Translations: Corpus Investigation of Revision and Self-revision. Master's Diploma Thesis, Department of English and American Studies, Masaryk University.

“Treaty of Versailles, (1920)". Encyclopedia of the Modern Middle East and North Africa, Ecyclopedia.com. 6 August 2018, htt//wwwecyclopedia.com.

Tchoungui, G. (1983). "Focus on official bilingualism in Cameroon: its relationship to education”. In Koenig, E. et al (eds.), 93-115.

Tso, B. W. (2010). “An Explorative Chapter on Translation and Translation Studies (Module One)," PhD Thesis, College of Arts and Law, University of Birmingham.

Wanchia, T. N. (2016). Towards a framework for translating Cameroonian creative popular orality. African Journal of Social Sciences (AJOSS) 7, (3), 2016, pp. 13-32.

Wanchia, T. N. (2012). The (Un)translatability of Cameroonian Popular Theatre. Unpublished PhD Thesis in Applied Linguistics/Translation, University of Buea.

Zangue, G. F. (2014). Traduction des concepts juridiques du français vers le Ngiemboon. Unpublished M.A Thesis in Translation, ASTI, University of Buea. 